\title{
BRAIN NEUROSECRETORY SYSTEM AND RETROCEREBRAL ENDOCRINE GLANDS OF ACRIDA BICOLOR (THUNB) (ORTHOPTERA: ACRIDIDAE)
}

\author{
AYDIN OZLÜK \\ Department of Biology, Faculty of Science, Ankara University, Ankara, Turkey.
}

(Received September 24, 1990; Accepted April 14, 1991)

\section{ABSTRACT}

The neurosecretory system and retrocerebral endocrine glands of $A$. bicolor were revealed by histological sections and whole mount, using Chrome Hematoxylin Phloxine and Performic Acid Victoria Blue techniques.

In account for the neurosecretory granules and their staining properties, one type neutosecretory cell was identified in sections. There was no difference between the histology of neurosecretory cells and syncytial corpora cardiaca of female and male individuals. It was observed that the females were bigger than the males and they had also bigger corpora allata.

The median neurosecretory cells and their emerging axons in the brain were not seen by total staining. However, in the same total stained preparates the outer parts of nerve corporis cardiaci-I and the storage lobe of the corpus cardiacum were stained in various density at different times of a day. So, it was concluded that the neurosecretory materials were transported by the nervi corporis cardiaci-I and that the neurohaemal organ was corpora cardiaca in this species.

\section{INTRODUCTION}

In recent years the importance of endocrine centers in insects has increased evidently in vertebıates. The neurosecretory cells are located in the brain of insects. Similar cells have also been demonstrated in vertebrates (SCHARRER and SCHARRER, 1944). The neurosecretory cells in the central nervous system control many major physiological events in the post embriyonic life of insects. The role of neurosecretory cells in the pars intercerebralis during moulting and metamorphosis is well known (WIGGLESHWORTH, 1972). In some insects these cells are also involved in ovarian development and oviposition (NAYAR, 1958; MORDEU, 1965; ADAMS, 1970). 
A review of the literature reveales many studies of the brains and the retrocerebral complex of different insects in which portions of this system were described. The brain neurosecretory centers and their related endocrine organs and nervous connections have also been totally and histologically investigated in most insects (DAY, 1943; TOPCUOGLU, 1972; ADAMS, 1976; DORTALND, 1979; DAVEY, 1981).

The neurosecretory cells can be classified as different cell types according to their staining reactions and various other properties (SHAIFQ, 1954; TOMBES and SMITH, 1970; WIGGLESHWORTH. 1972). In the study of the neurosecretory system, the in situ technique of staining has been proved to be very useful, especially in insects (DOGRA and TANDAN, 1964; DOGRA, 1967).

The CC and the CA are located in the posterior part of the head of insects and anatomically connected in most insects. The CG have been shown experimentally to play some part in the control of developmental events (THOMSEN, 1954). It is thought that this control is affected by the release of material which originates in the neurosecretory cells in the brain, and passes through the NCC to the CG, where it accumulates (SCHARRER, 1952; THOMSEN, 1954).

The C. allatum is known to secrete a hormone which is often referred as "the Juvenile Hormone". It is known to influence a number of physiological process (MORDUE, 1965; PENER, 1967; ADAMS, 1970; PINES et al., 1980; PRATT and PENER, 1983).

The present study was undertaken to determine the anatomy and histology of the neuroendocrine complex of $A$. bicolor as an essential basis for future endocrine studies.

\section{MATERIAL and METHODS}

The male and female $A$. bicolor adults needed for the studies were collected from the vicinity of Ankara during summer months. They were kept in the cages and fed with fresh quitch grass and wheat until dissection. Since different species gave different results by the same staining technique (ARVY and GABE, 1962); the species Locusta migratoria migratorioides which has been studied very well (UVAROV, 1966) has been chosen in order to test whether the staining techniques work or not. L.m. migratorioides specimens were taken from the Zoology Laboratory in Department of Biology, Faculty of Science, University of Ankara. 
The brain and the retrocerebral endocrine glands of both insects were dissected in physiological saline and fixed in two lots. One lot was fixed in 10 per cent formol-saline and the other in Bouin's fluid. The former lot was stained with performic acid victoria blue (DOGRA and TANDAN, 1964) and the latter with chrome hematoxylin phloxine (GOMORI, 1941). For the histological observations, the organs were dehydrated by being subjected to the alcohols $(30 \%, 50,70,90,100)$ and supercedrol, supercedrol-paraffin wax and finally embedded in parafin wax and blocked. The serial sections were observed under a light microscope and the fotomicrographs were taken with an automatic camera mounted on Vanox research microscope.

The cerebral system of adult male and female of $A$. bicolor now has been studied with both PAVB and CHP staining technixues.

\section{RESULTS}

General Morphology

The brain is composed of protocerebrum, deutocerebrum and tritocerebrum (Fig. 1a). Protocerebium laterally has two well developed optic lobes, each size of which is about half of the brain and sends nerves
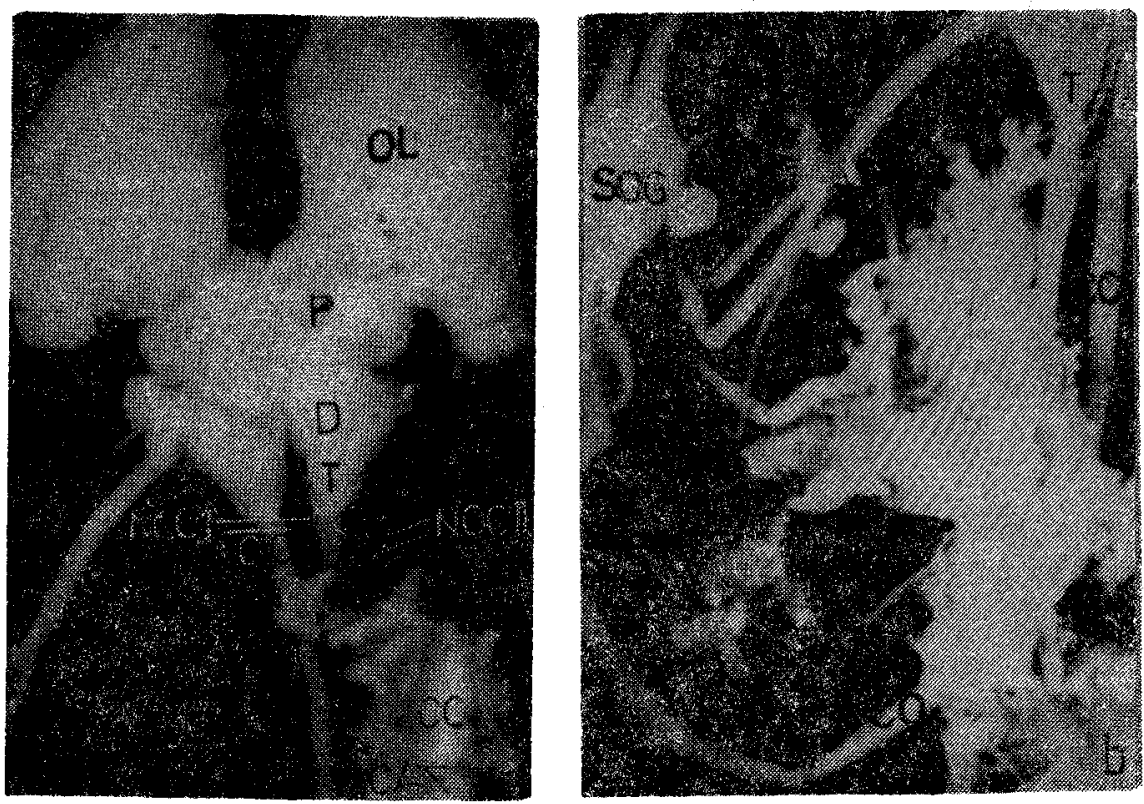

Fig. 1. Brain and retrocerebral endocrine glands (a) and the long linkage of suboesophageal ganglion' b) to the brain. $10 x$. 
two laterally and one medially to the ocellus. Deutocerebrum has two antennal lobes which recieve one thick nerve for each antennae. Tritocerebrum consists of two distioct lobes and links to suboesophageal ganglion with the pair of long connectives. The suboesophageal ganglion is situated extremely away from the brain and runs front of the brain. Because of the correlation with the long head morphology, the distance between the brain and the CC-CA complex is also far (Fig Ib).

The CC are a pair of translucent structures and located behind the brain. They lie on dorsal portion of the esophagus and surround the aorta. They are joined to the brain by two pair of very long nerves. One of them is a medial pair of CC nerves salled nervi corporis cardiaci-I. In addition to the NCC-I, another pair of nerves emerges from the mid posterior surface of the tritocerebrum, dorsal and lateral to the NCC-I, and joins the $\mathrm{CC}$ on their anterior surfaces (Fig. 2). They are clearly

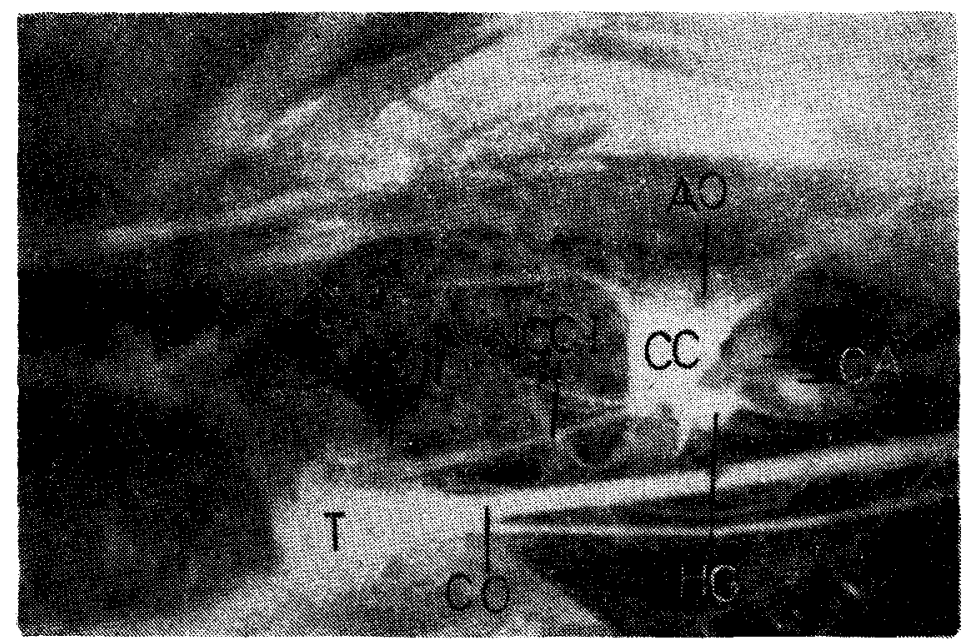

Fig. 2. Lateral view of retrocerebral endocrine glands. 10x.

visible after stretching the brain. These nerves are the nervi corporis cardiaci-II. The CC are connected to the hypocerebral ganglion by two short, thick connectives (Fig. 2). A fine pair of nerves, the nervi corporis allati-I, connects the CA to the CG. These nerves axe located on each side of the lateral line of the esophagus and link to the suboesophageal ganglion. In adidtion to the NCA-I which connects themselves to the C. cardiacum they are connected by fine nerves to the suboesophageal ganglion with NCA-II (Fig. 8b). 
The body of the female individuals is normally bigger than that of the males. When their bodies are compared, it is seen that the bigger female individuals have the larger brain and retrocerebral endocrine glands than those of the males. This especially can be seen clearly in the sections of CA (Fig. 8a, b).

\section{Total Staining}

The photomicrographic demonstration of the median neurosecretory cells and their axonal pathways in the total stained preparations of $A$. bicolor involve in some difficulty. The stainable material of the median neurosecretory cells of pars intercerebralis, and its axons were not seen in the brain with PAVB staining (Fig. 3a). However, when the same technique was applied to L.m. migratorioides, it was observed that they were stained dark-blue. The cross of the emerging axons from the neurosecretory cells in the pars intercerebralis had also been clearly seen (Fig. 4). But the parts of NCC-I extended out of the brain and the storage lob of the CC of $A$. bicolor have been stained with this technique (Fig. 3a, b).
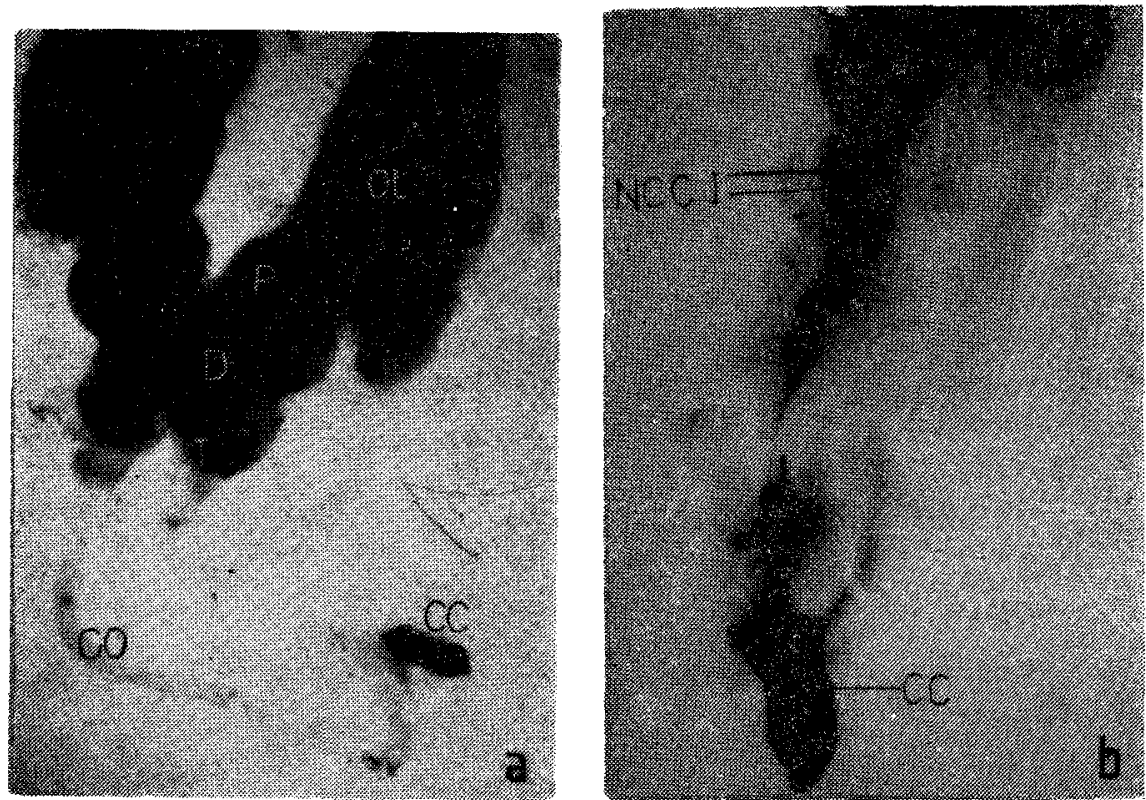

Fig. 3. Brain and CC after total staining in $\mathrm{f}$. bicolor (a). 10x. The exist of stainable material in CC and NCC-I (b). 25x: 


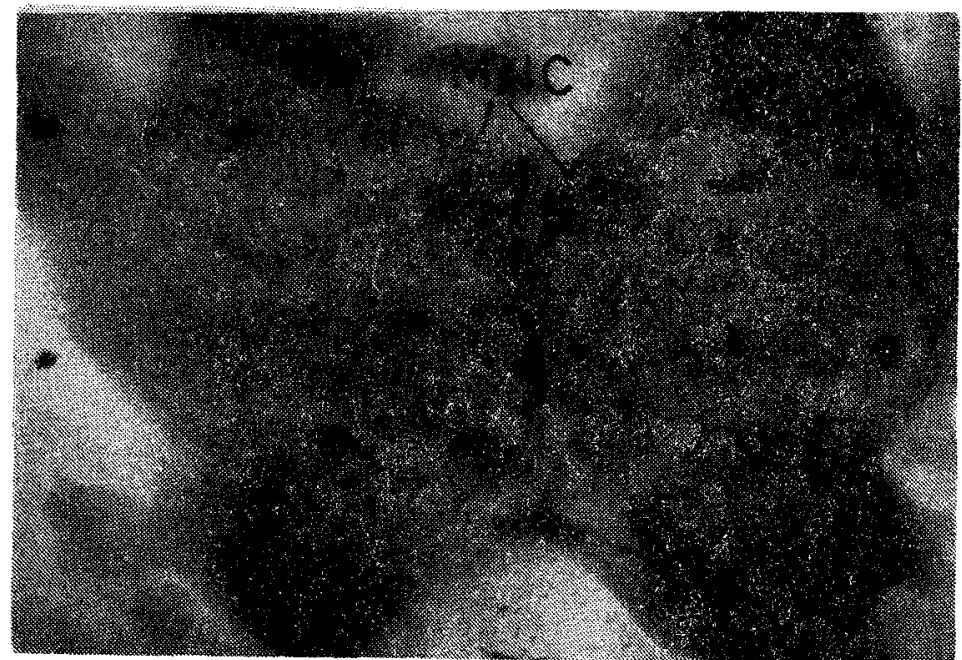

Fig. 4. The cross of the emerging axons from the median neurosecretory cells after total staining in the brain of L.m migratorioides. 30x.

In the stained areas of $A$. bicolor which were fixed at different times of a day, the density of the colouration of the stainable material was various. The fluctuation of the density in these areas shows the different stages of the secretion from the brain neurosecretory cells and it also shows that this secretion is storaged and secreted in the CC. These observations revealed that the neurosecretory material was transported by the NCC-I to the CC, and therefore the neurohaemal organ was the CG in this species.

The point of origin of NCC-II in the brain can not be made out because the pathways of the lateral neurosemetory cells have not also been observed in both species. Additionally, the NCA-I, CA and NCA-II. were not also been stained in these species.

\section{HISTOLOGICAL RESULTS}

\section{Neurosecretory Cells}

The neurosecretory cells can he seen in the protocerebral, deutocerebral and tritocerebral regions of the brain (Fig. $5 \mathrm{a}, \mathrm{b}$ ). The neurosecretory cells in the protocerebrum can be identified as follows: Some neurosecretory cells exist in the dorsal part of the pars intercerebralis as two closely placed small part, four or five cells lie in the two group at 
the mid line of the anterio-ventral region, and one or two neurosecretory cells are situated at the bottom of the optic lobes on both side of the protocerebral lobes (Fig. 5 b).
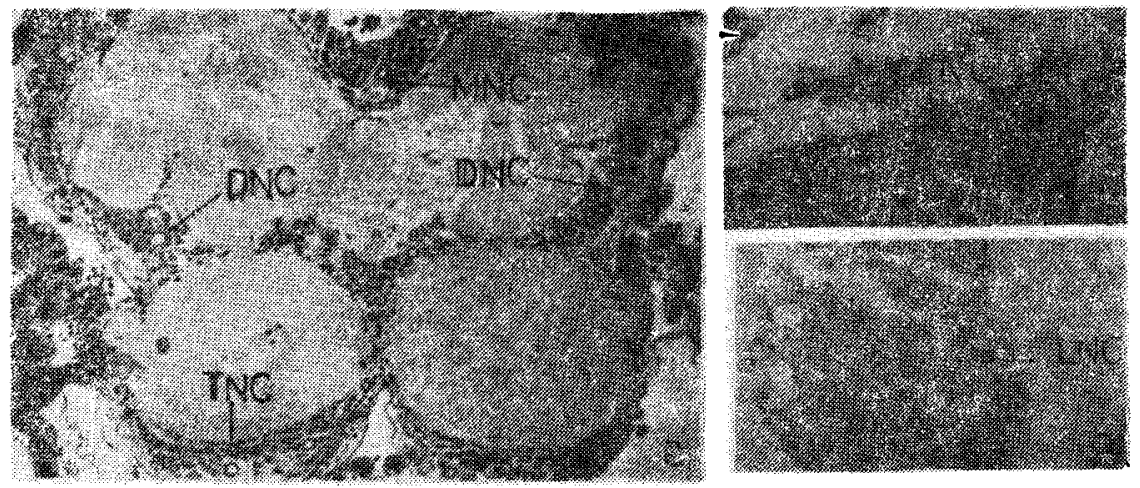

Fig. 5. The neurosecretory cells in the protocerebruf, deurocerebrum and tritocerebrum (a). 25x. The neurosecretory cells at the bottom of the optic lobe (b) and lateral of protocerebrum (c). $100 x$.

The neurosecretory celis can be distinguished from normal neurons by their large nuclei and cytoplasm. They contain some inclusions which stain dark bluish purple or reddish on the pink or pink-violet cytoplasm with CHP (Fig. 6a).
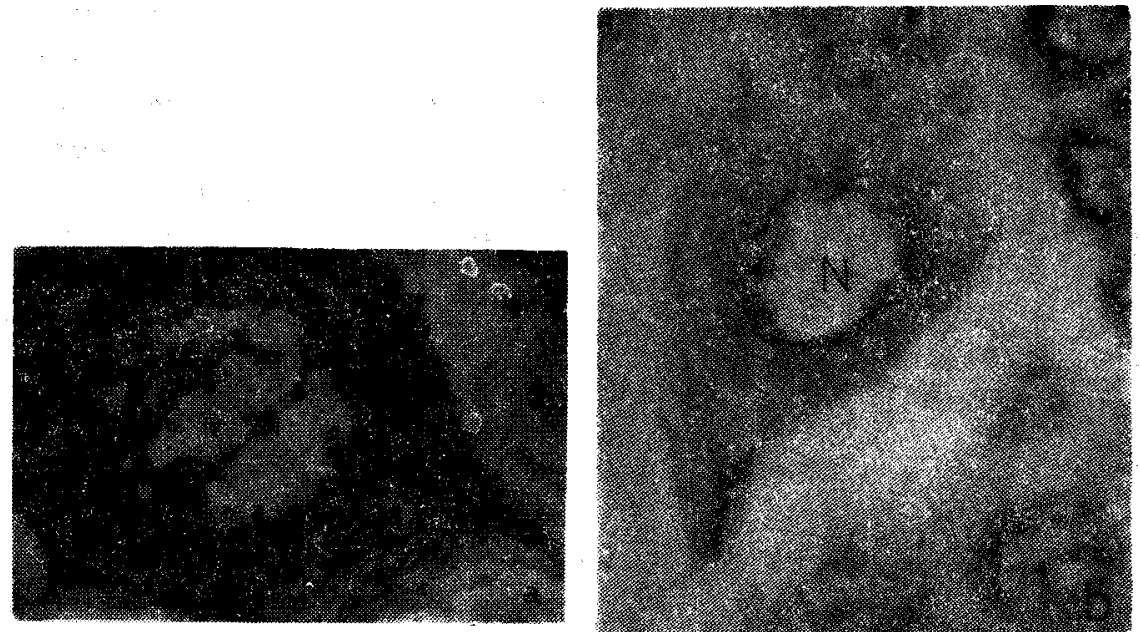

Fig. 6. The neurosecretory cells can be distinquished from normal neurons by their large nuclei and cytoplasm (a). $400 \mathrm{x}$. The neurosecretory cell in pyxiform (b). $250 \mathrm{x}$. 
The classification of neurosecretory cells into different groups according to their cyrtoplasmic inclusions and differentiation and staining reactions is not possible. There is also no clear variation according to the size and differentiation of the cytoplasmic inclusions in the neurosecretory cells in the adult male and fernale individuals. But, there are some neurosecretory cells of a pyriform shape (Fig. 6b). Small inclusions are scattered in the cell bodies. There are no densely packed granules in the neurosecretory cells. There is no visible difference between the female and male neurosecretory cells and their locations in the brain.

Corpora Cardiaca

The corpora cardiaca lie posterior to the brain and overlic to the hypocerebral ganglion (Fig. 2). Dorsal aorta passes between the two glands. The CC are separated ventrally and dorsally except for a short region of contact mid-dorsaily. The $\mathrm{CC}$ are composed of two histologically distinct regions. The major portion of the gland consists of axons of the NCC-T, cells with flattened or spherical shape. Stainable material is absent in the posterior ventral regions of the gland. The posterior lobes form a narrower portion of the gland, dorsal to the large anterior lobes, and their outlines are undulated. The anterior of the CC is " $U$ " shaped and its unpaired lobe is situated immediately above the hypocerebral ganglion.

It is possible to see the cell boundary, but the cytoplasm is generally syncytial. The nuclei are ellipsoid or circular (Fig. 7a). Same small inclusions stained dark blue with CHP as in the neurosecretory cells appeared scattered in the cytoplasm of the paired anterior lobes, especially near the aorta. In some sections, the dark blue granules coming from the brain neurosecretory cells are collected in the anterior lobes, which are neurohaemal organ. There was no indication about the secretion of the posterior $\mathrm{CC}$.

Corpora Allata

The corpora allata are paired ellipsoidal bodies. They were located on both side of eosophagus, and ventral to the CC (Fig. 2). The CA were connected to the CC by the NCA-I (Fig. 7b) and it was also possible to see nerves emerging from the posterior side of the CA (Fig. 8b), extending to the suboesophageal ganglion. The axons of NCA-I can be followed into the central region of the CA. Stainable material was observed neither in the axons of these nerves nor in the cells of the CA. 

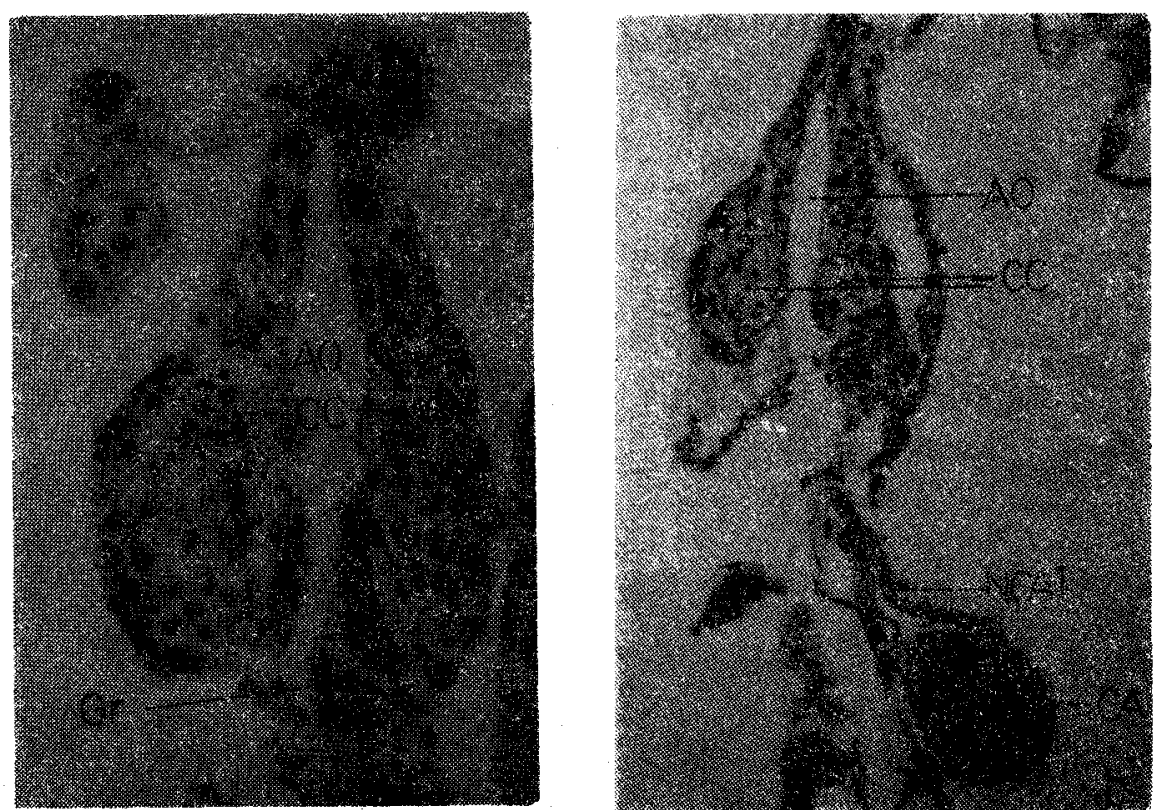

Fig. 7. Section through anterior and posterior C. cardiaca (a). 70x. C. cardiaca and its connection with C. allata (b). $50 x$.

The corpus allatum showed a syncytial structure. It was sometimes possible to distinquish cell boundaries (Fig. 8a, b). The CHP stained the
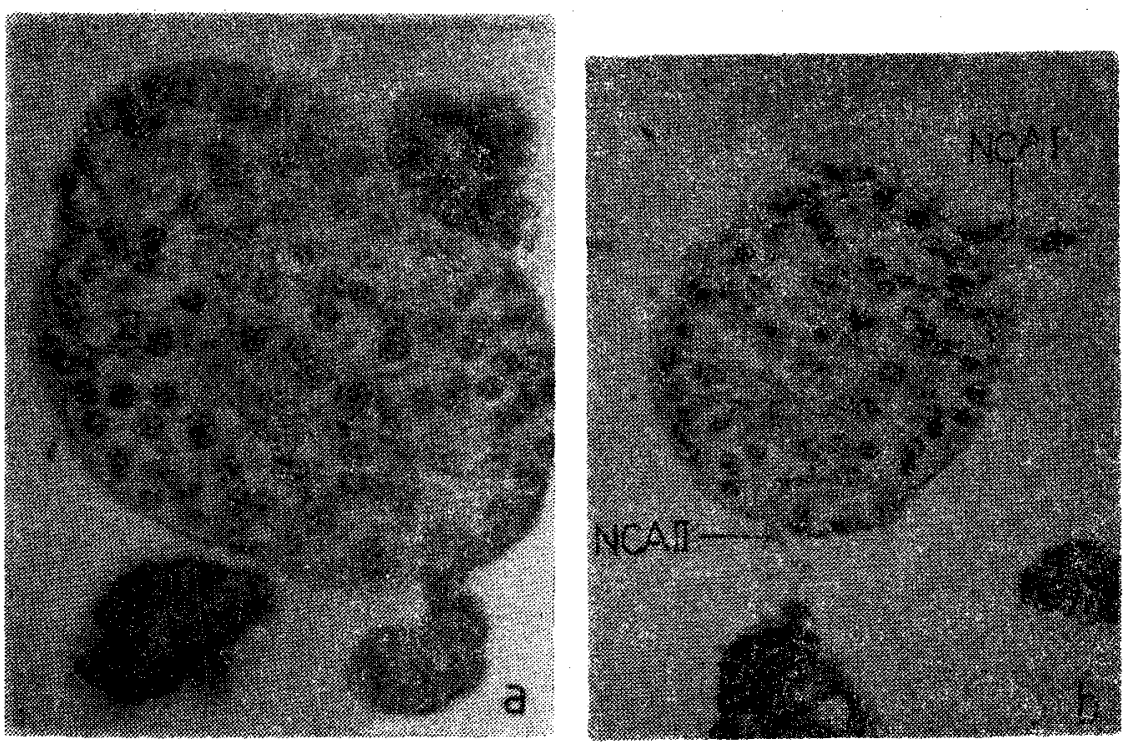

Fig. 8. The female (a) and male (b) corpus allatum. 100x. 
nuclei in blue violet. The nuclei of the gland cells were round and sometimes ellipsoidal.

In sections, it is possible to see the size difference between the female (Fig. 8a) and the male (Fig. 8b) corpus allatum which is correlated to body size.

\section{DISCUSSION}

In the study of neurosecretory system, the total staining has been proved to be very useful, particularly in insects (DOGRA, 1967; AWASTHJ, 1972; TOPÇUOĞLU, 1972). By total staining in A. bicolor the median and lateral neurosecretory cells and their emerging axons in the brain were not seen, In. L. m. migratorioides which was stained at the same time as $A$. bicolor to test the staining technique, the areas in question were seen. Histochemical investigation of the neurosecretory product of the pars intercerebralis of 15 species of insect belonging to 9 different order was proved by Arvy and Gabe (1962). They claimed that the median neurosecretory cells were different biochemical structure in different pterygote species and that there was a stain proof strong tissue around the neurosecretory cells in certain species. Indeed, the staining of the parts of the NCC-I other than its brain with the same method supports the idea that there is a stain-proof tissue around them. From this observations, it is obvious that the PAVB reactivity of the neurosecretory cells in Metochus uniquttatus is of different biochemical structure (AWASTHI, 1973).

It is known that the amount of the neurosecretory material in the brain varies according to the physiological states of the insect (HOFMANN, 1970) and the NCC-I transports the neurosecretory material coming to the CC. Supporting this idea, the density of the neurosecretory material in the $\mathrm{CC}$ varies in $A$. bicolor which are fixed at different times of a day, and the parts of NCC-I exiended out of the brain in some preparations fixed probably at times, when there is no transport, were not stained.

The neurosecretory cells in the head region of the female and male A. bicolor are found in the protocerebrum, deutocerebrum and tritocerebrum. There are a number of neurosecretory cells seattered at the periphery of the protocerebrum (especially in the median, lateral and ventromedial regions) as in Periplanata americana L. (KHAN and FRASER, 1962). It is thought that the location and apperarance of these cells are 
similar to those cells which are found in Anacridium aegyptium, Acheta domesticus, Melanogryllus desertus (GELDIAY, 1973). Melanoplus san-guinipes (DOGRA and EVEN, 1970).

Some authors showed the different types of neurosecretory cells by their variations in size and selective stainability with $A F$ and CHP (NAYAR, 1955; EVEN, 1962). Nayar (1955) classified the neurosecretory cells into " $A$ " and " $B$ " types, and later Johannsson (1958) and Highnam (1961) divided the cells into four types. But in $A$. bicolor only one type is recognizable. These stained blue or blue-black with CHP. However, in Anacridium aegyptium (GELDİY, 1967), Acheta domesticus (GELDIAY, 1973) and Galeruca tanaceti L., (SIEV, 1965) they can be distinguished by the use of CHP.

On histological ground there is much evidence to support the idea that the cells I have described above are indeed neurosecretory. However, the failure of CHP to selectively stain the cells has been considered in most other insects (ARVY and GABE, 1962; HIGHNAM, 1962; AWASTHI, 1976).

The morphology of the brain of $A$. bicolor is similar in general organisation to the descriptions given for other orthoptera (NESBITT, 1941; WILLEY, 1961).

As has already been stated, the corpora cardiaca are structually similar to their counterparts in Locusta migratoria and Schistocerca gregaria (HIGHNAM, 1961) and Melanoplus sanguinipes (DOGRA and EVEN, 1970) in that they are histologically divisible into two regions. Mason (1973) has shown in Schistocerca vaga, the fibers of the NCC-I and mainly in the anterior region of the CC. It is this region of the CC that serves for the storage of neurosecretory material from the brain. This is most probably true of $A$. bicolor since material with similar staining properties was observed in the NCC-I and in this region of the CC.

In general CA of $A$. bicolor are similar, histologically to the CA of other orthoptera (MENDES, 1948; JOLY, 1968). Neurosecretory material, at least, at the light microscope level, was never observed in the cells of the CA or along the axons of the NCA-I and the NCA-II, although other authors have reported stainable material in these regions of other species (SCHARRER, 1964; AWASTHI, 1968). In A. bicolor, as in Schistocerce vaga (MASON, 1973) the NC.A-II connect the CA to the suboesophageal ganglion. 


\section{ACKNOWLEDGEMENTS.}

I am grateful to my adviser Prof. Sr. Süheyla Küçükekşi for her advice and also to Dr. Hakk Sayar for his helps throughout this work.

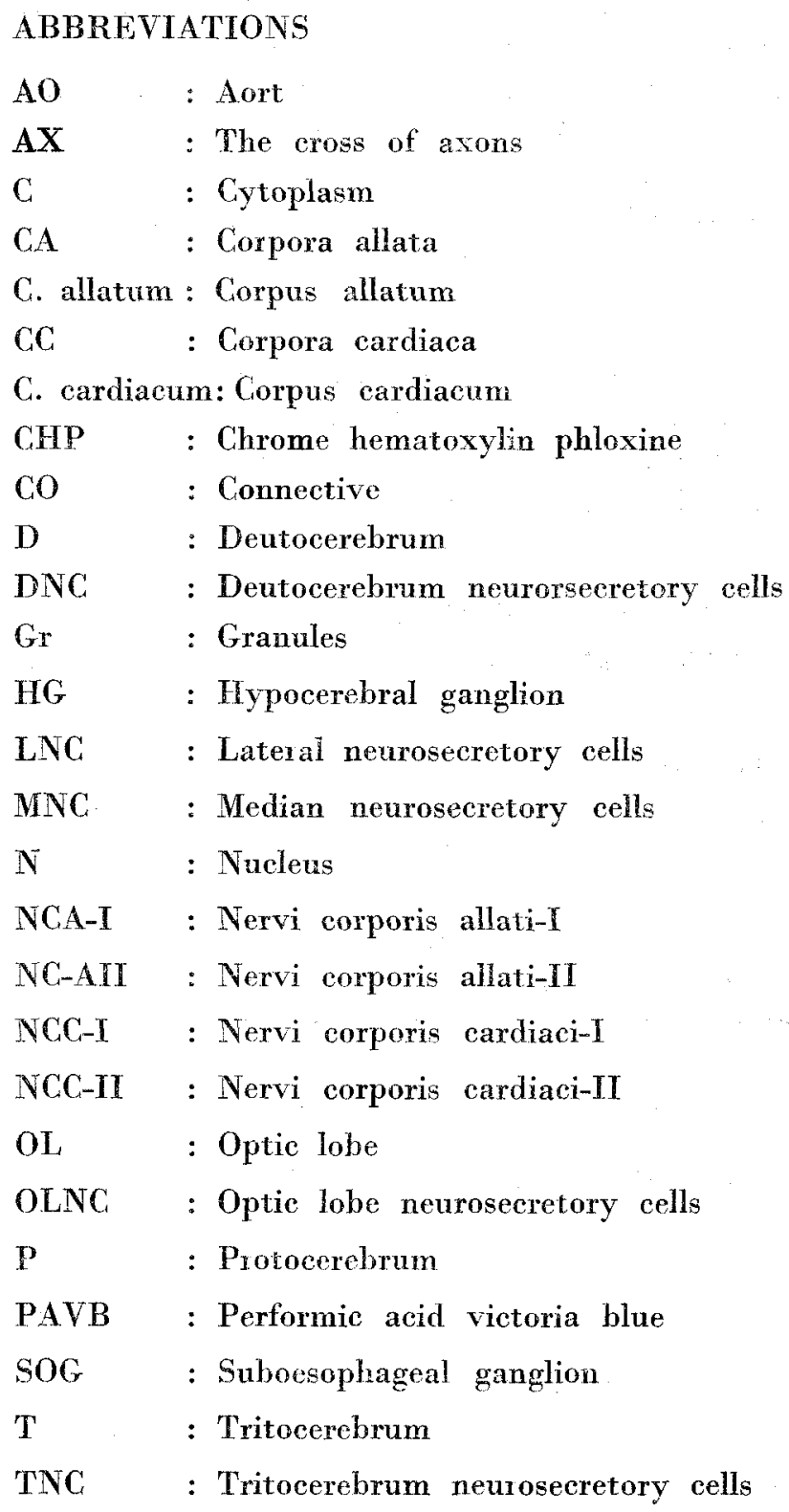




\section{REFERENCFS}

ADAMS, T.S., 1970. Ovarian regulation of the corpus allatum in the housefly, Musca domestica. J. Insect Physiol, 16:349-360.

1976. The ovaries ring gland and neurosecretion during the second gonotropic cycle in the housefly, Musca domestica. Gen. Comp. Endocrinol., 30:69-76.

ARVY, L. and M. GABE, 1962. Histochemistry of the neurosecretory product of the pars intercerebralis of pterygote insects. Neurosecretion. HELLER, H. and R.B. CLARK., 331-334.

AWASTHI, V.G., 1968, The functional significance of the nervi corporis allati I and nervi corporis allati II in Gryllodes sigillatus. J. Insect Physiol., 14:301--304.

1972. Neurosecretory system of the adult flesh-fly Sarcophaga ruficornis. F., J. Insect Morphol. and Embryol., 1 (2): 133-140.

1973. Neurosecretory system and retrocerebral endocrine glands of Methochus uniguttotus THUNB. (HETEROPTERA: LYGAEDIAE). J. Insect Morphol. and Embryol., $2(1): 1 \div 12$.

1976. Neurosecretory cells and aorta as a neurohaemal organ in the earwig Euborellia annulipas LUCAS (DERMAPTFRA: LABODURIDAE). J. Insect Morphol. and Embryol., 5 (4/5): 253-260.

DAVEY, K.G., 1981. Hormonal control of vitellogenesis uptake in Rhodniue prolixis stall. Amer. Zool. 21: 701-705.

DAY, M.F., 1943. The function of the corpus allatum in Muscoid diptera. Bioll. Bull., 84 (2): $127-140$.

DOGRA, G.S. and K.B. TANDAN., 1964. Adaptation of certain histological techniques for in situ demonstration of the neuroeondocrine system of insect and other animals. Quarts J. Mic. Sci., 105: 445-466.

DOGRA, G.S., 1967. Studies on the neurosecretory system and the functional significance of NSM in the aorta wall of the bug Dysdercus koenigii. J. Insect Physiol., 13: 1895-1906.

DOGRA, G.S. and A.B. EWEN, 1970. Histology of the neurosecretory system and the retrocerebral endocrine glands of the adult migratory grasshopper Melpnoplus sangunipes (Fab) Orthoptera: Acrididae. J. Morphol., 130: 451-466.

DORTLAND, J.F., 1979. The hormonal control of vitellogenin synthesis in the fat body of the female Colorada Potato Beetle. Gen. Comp. Endocrinol., 38: 332-344.

EVEN, A.B., 1962. Histophysiology of the neurosecretory system and the retrocerebral endocrine glands of the alfalfa plant bug. Adelphocoris liner Tratus (Goeze) (Hemiptera: Mridae). J. Morph., 111: 253-273.

GELDIAY, S., 1967. Hormonal control of adult reproductive diapause in the Egyptian grasshopper, Anaeridium aegyptium I. J. Endoc., 37: 63-71.

1973. Anac idium aegyptium L. Acheta domestica L. Melanogryllus desertus pall. Ùe orthopter beynindeki yeni nörosekresyon merkezi üzerinde histolojik, stolojik otoradyografik araştırmalar. Ege Ùniv. Ilmi Raporlar Serisi No: 190. 
GOMORI, G., 1941. Observation with differential stains on human islets of langerhans. Amer. J. Path., 17: 395-406.

HIGHNAM, K.C., 1961. The histology of the neurosecretory system of the adult female desert locust Schistocerca gregaria Quart. J. Mic. Sci., 102: 27-38.

1962. Neurosceretory control of ovarian development in the desert locust Schistocerrea gregaria. Neuronecretion. Heller, $\mathrm{H}$ and Clark, R.B., 379-390.

HOFFMANN, H.J., 1970. Neuro-endocrine control of diapause and oöcyte maturation in the beetle Pterosichus nigrita. I. Insect Physiol. 16: 629-642.

JOHANSSON, A.S., 1958. Relation of nutrition to endocrine-reproductive functions in the mikweed bug Oncopeltus fasciaizs (Dallas) Hymenoptera: Lygaeidae). Nytt. Mag. Zool., 7: $5-132$.

JOLY, P., 1968. Anatomic ed I'appareil endocrine des insectes. "Endoctinologie Des Insectes." Editeur MASSON ET Cle, Paris., 37-79.

KHAN, T.R. and A. FRASER., 1962. Neurosecretion in the embryo and later stages of the cockrach Periplereta americana L. Neutosecretion. Heller, H and Clark, R.B., 349-369.

MASON, C.A., 1973. New features of the brain-retrocerebral neuroendocrine complefx the locust Schisiocerca vaga (Scudder). Z. Zellforsch., 141: 19-32.

MENDES, M.V., 1948. Histllogy of the corpora allata of Melanoplus differentialis (Orthoptera: Saltatoria). Biol. Bull,, 94. (1): 194-207.

MORDUE, W., 1965. The reuroendocrine control of oöcyte development in Tenebrio molitor L.J. Insect Physiol., 11: 505-511

NAYAR, K.K., 1955. Studies on the neurosecretory system of Iphitalim bata STAL. I. Distribu tion and structure of the neurosecretory cells of the nerve ring. Biol. Bull, 112: 206-307.

1958. Studies on the neurosecretory system of Iphita limbata STAL. V. Probable endocrine basis of oviposition in the female insect. Proc. Indian Acad. Sci. (B). 47: 233-251.

NESPITT, H.H.J., 1941. A comparative morphological study of the nervous system of the Orthoptera and related orders. Ann. Entomol. Soc. Amer., 34: $51-81$

PENER, M.P., 1967. Effects of allatectomy and sectioning of the nerves of the corpora allata on oöcyte growth, male sexual behavior, and colour changes in adult Schistoserca gregaria J. Insect Physiol., 13: 665-684.

PINES, M., E. LUMBZENS, P. HARRY, and S.W. APPLEBAUM., 1980. Disparity between in vivo and in vitro synthesis of yolk protein by fat brodies of vitellogenic Locusta mihratoria after allatectomy. Gen. Comp. Fndocrinol, 41: 417-420.

SCHARRER, E., and S. SCHARRER., 1944. Neurosecretion VI. A comparison between the intercerebralis-cardiacum-allatum system of the insects and the hypotalamo-hypophyseal system of vertebrates. Biol. Bull., 37: 242-251

SCHARRER, E., 1952. Neurosecretion, XI The effect of the nerve section on the intercerebralis mcardiacum-allatum system of the insect Leucophac moderae. Biol. Bull., 102: 261-272. 
SCHARRER, B., 1964. Histopahysiological studies on the corpus allatum if Leucophaea maderae. IV. Ultrastructure during normal activity cycle. Z. Zellforsch., 62: 125-148.

SHAIFQ, S.A., 1954. A study of the embriyonic development of gooseberry sawfly, Pternoidea ribesii. Q. Jour. of Mic. Sci., 95: 93-114.

SIEW, Y.S., 1965. The endocrine control of adult reproductive diapause in the chrysomelid beetle Galeruca tanaceti L. III. J. Insect Physiol., 11: 973-981.

THOMSEN, M., 1954. Neurosecretion in some Hymenoptera. Dan. Biol. Skr., 7: 1-24

TOMBES, A. and D.S. SMITH, 1970. Ultrastructural studies on the corpus cardiacum- allatum complex of the adult alfalfa meevil, Hypera postica. J. Morph., 132-147.

TOPÇUOGLLU, N., 1972. Mısır çekirgesi (Anacridium aegyptium L.) beyin ve ona bağh endokrin merkezlerin morfolojisi. Ege Úniv. Fen Fakültesi Ilmi Raporlar Serisi No: 131

UVAROV, B., 1966. Grasshoppers and locust. Cambridge puplished for the anti-locust research centre. Vol: 1

WIGGLESHWORTH, V.B., 1972. The principles of insect physiology. 178-214.

WILLEY, R.B., 1961. The morphology of the stomodeal nervous system in Periplaneta americana (L.) and other Blatteria. J. Morph., 108: 219-262. 